University of Rhode Island

DigitalCommons@URI

The Rhode Island Current Conditions Index

Economics

$12-2006$

\title{
Rhode Island Current Conditions Index - December 2006
}

Leonard Lardaro

University of Rhode Island, lardaro@uri.edu

Follow this and additional works at: https://digitalcommons.uri.edu/ricci

Part of the Econometrics Commons

Terms of Use

All rights reserved under copyright.

\section{Recommended Citation}

Lardaro, Leonard, "Rhode Island Current Conditions Index -- December 2006" (2006). The Rhode Island Current Conditions Index. Paper 71.

https://digitalcommons.uri.edu/ricci/71

This Article is brought to you for free and open access by the Economics at DigitalCommons@URI. It has been accepted for inclusion in The Rhode Island Current Conditions Index by an authorized administrator of DigitalCommons@URI.For more information, please contact digitalcommons-group@uri.edu. 


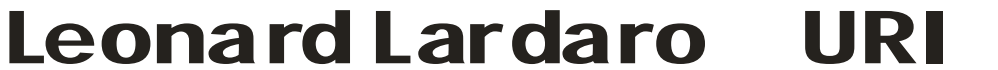

Rhode Island ended 2006 on a positive note, sustaining the enhanced pace of economic activity that began after the end of the third quarter. The Current Conditions Index for December was 58, with seven of twelve indicators improving. Unlike the past couple of months, however, only three of this month's improving indicators turned in strong performances, while three key labor market indicators turned negative for the second consecutive month.

The strongest performances in December were for Retail Sales, Employment Service Jobs, and Total Manufacturing Hours. I mportantly, the latter two are leading indicators, pointing to some potential strength as we move into 2007. Retail Sales grew by an amazing 9.9 percent

\begin{tabular}{lc}
\multicolumn{2}{c}{ CCI Indicators - \% Change } \\
Government Employment & -1.2 \\
US Consumer Sentiment & $0.3 \mathbf{Y}$ \\
Single-Unit Permits & -24.9 \\
Retail Sales & 9.9 Y \\
Employment Services J obs & 6.1 Y \\
Priv. Serv-Prod Employment & $0.5 \mathbf{Y}$ \\
Total Manufacturing Hours & $4.8 \mathbf{Y}$ \\
Manufacturing Wage & 1.1 Y \\
Labor Force & 0.9 Y \\
Benefit Exhaustions & 3.6 \\
New Claims & 3.4 \\
Unemployment Rate & 2.0 \\
\multicolumn{1}{|c}{ Y = I mproved Value } &
\end{tabular}

compared to last December, its most rapid rate of growth since January of 2006, signaling a strong end to the holiday shopping season. While some retailing strength was likely related to weather considerations, its rapid rate of growth was also noteworthy since it occurred along with anemic growth in US Consumer Sentiment $(+0.3 \%)$. Employment Service Jobs, which includes temporary employees, rose by 6.1 percent, marking its best performance since March of 2005. This sharp uptick in Employment Service J obs growth might signal a more rapid pace of job growth in the coming months. Actually, my work suggests that when rebenchmarking occurs with January data, we will find that employment was actually higher than indicated by the originally released numbers.

In December, Rhode Island's manufacturing sector turned in its first solid performance in years. The Manufacturing Wage rose by 1.1 percent in December, its slowest rate of growth in over a year, but more importantly, Total Manufacturing Hours rose by 4.8 percent, its second consecutive increase, a "string" we haven't witnessed since the year 2000. This month's performance by Total Manufacturing Hours was driven by an increase in the length of the manufacturing work week which offset a decline in the number of manufacturing employees.

That's where the good news ends. Government Employment fell sharply (by 1.2\%), Private Service Producing Employment growth was very slow, at 0.5 percent, and Labor Force growth remained below one percent. More importantly, a critical labor market "pair" failed to improve for the second consecutive month. New Claims for Unemployment Insurance, which measures layoffs, rose by 3.4 percent in December, very likely signaling the end of its downward trend in earlier months. On the other end of the layoff spectrum, Benefit Exhaustions, which reflects longterm unemployment, increased again, by 3.6 percent in December. Along with all of this, our Unemployment Rate rose slightly from 5.1 percent last December to 5.2 percent this December. Finally, December's worst performer was Single-Unit Permits, which reflects new home construction. This indicator continued its roller coaster ride, falling by almost 25 percent compared to last December.

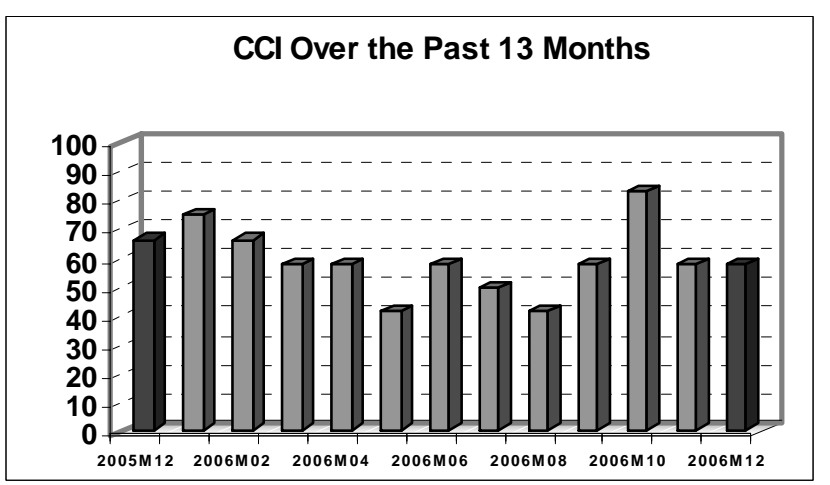

\section{THE BOTTOM LINE}

The year 2006 will go down as one of contrasts. We started the year with strong momentum, slumped midyear, then rebounded as the year came to a close. Let's hope momentum remains strong, as major budget balancing will surely take its toll on our state's growth.

\begin{tabular}{|c|c|c|c|c|c|c|c|c|c|c|c|c|}
\hline & Jan & Feb & Mar & Apr & May & J un & $\mathrm{J}$ ul & Aug & Sep & Oct & Nov & Dec \\
\hline 2005 & 50 & 67 & 50 & 50 & 42 & 75 & 58 & 67 & 42 & 58 & 58 & 67 \\
\hline 2006 & 75 & 67 & 58 & 58 & 42 & 58 & 50 & 42 & 58 & 83 & 58 & 58 \\
\hline
\end{tabular}

